ENVIRONMENTAL SCIENCE AND RESEARCH FOUNDATION REPORT SERIES, NUMBER 015

ISSN 1089-5469

\title{
In Summary: \\ Idaho National Engineering Laboratory Site Environmental Report for Calendar Year 1995
}

\author{
Donny Roush . \\ Russell G. Mitchell \\ Don Peterson
}

Environmental Science and Research Foundation

Doyle Markham, Executive Director

August 1996

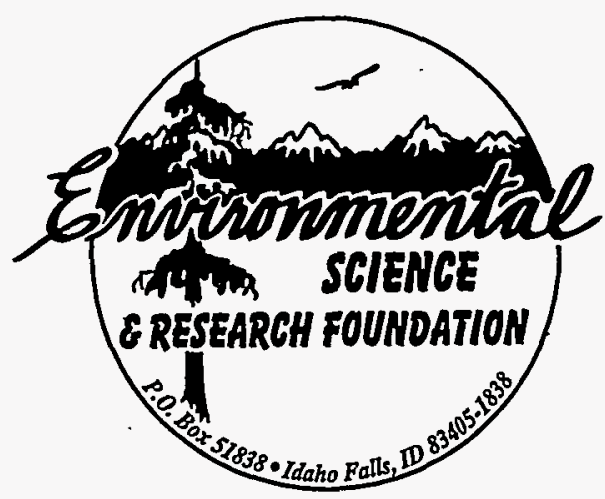

Program Conducted for the U.S. Department of Energy under

Contract DE-AC07-94ID13268 by the

Environmental Science and Research Foundation

I0I S. Park Avenue, Suite 2

P.0. Box 51838

Idaho Falls, Idaho 83405-1838

ESBTRIBUTION OF THIS DOCUMENT IS UNLIMITED 


\section{DISCLAIMER}

This report was prepared as an account of work sponsored by an agency of the United States Government. Neither the United States Government nor any agency thereof, nor any of their employees, makes any warranty, express or implied, or assumes any legal liability or responsibility for the accuracy, completeness, or usefulness of any information, apparatus, product, or process disclosed, or represents that its use would not infringe privately owned rights. Reference herein to any specific commercial product, process, or service by trade name, trademark, manufacturer, or otherwise does not necessarily constitute or imply its endorsement, recommendation, or favoring by the United States Government or any agency thereof. The views and opinions of authors expressed herein do not necessarily state or reflect those of the United States Government or any agency thereof. 


\section{DISCLAIMER}

Portions of this document may be illegible electronic image products. Images are produced from the best available original document. 


\section{THE INEL'S ENVIRONMENT DURING 1995 AT A GLANCE}

Each year, the state of the environment at the Idaho National Engineering Laboratory (INEL) is assessed in a Site Environmental Report. The Environmental Science and Research Foundation compiles data collected from rountine environmental monitoring programs conducted on and around the INEL. Recently, the report Idaho National Engineering Laboratory Site Environmental Report for Calendar Year 1995 was prepared and published. The Environmental Science and Research Foundation prepared this summary to highlight findings from that report.

- Scientists from the Environmental Science and Research Foundation, Lockheed Martin Idaho Technologies Company, the U. S. Geological Survey, and other Idaho National Engineering Laboratory (INEL) contractors monitored the environment on and around the INEL to find contaminants attributable to the INEL. During 1995, all exposures from the INEL to the public were negligible.

- Pathways by which INEL contaminants might reach people were monitored. These included: air, precipitation, water, soil, locally grown food (wheat, milk, potatoes, and lettuce), game animals, and direct radiation.

- According the 1995 's results, nearly all radioactivity related to INEL operations was not distinguishible from natural radioactivity and worldwide fallout from nuclear weapons testing carried out in the 1950s and 1960s. Radiation from natural sources and weapons testing is called "background radiation."

- The man-made radionuclides americium, plutonium, and strontium were found in the air at four locations on the INEL. Contaminants in air around the Radioactive Waste Management Complex were linked to construction activities which resuspended contaminated soil into the air. No source was determined for plutonium detected at the Idaho Chemical Processing Plant and Power Burst Facility. The concentrations of these radioactive substances were well below health and safety. standards.

- Because radiation from the INEL was not detected by offsite environmental surveillance methods, computer models were used to estimate a radiation dose to people. The hypothetical maximum individual dose from the INEL was calculated to be 0.018 millirem. That's 0.005 percent of an average person's annual dose from background sources in southeast Idaho. 


\section{Introduction}

Every human is exposed to natural radiation. This exposure comes from many sources, including cosmic radiation from outer space, naturally-occurring radon, and radioactivity from substances in our bodies. In addition to natural sources of radiation, humans can also be exposed to manmade sources of radiation. Examples of man-made sources include nuclear medicine, X-rays, nuclear weapons testing, and accidents at nuclear power plants.

The Idaho National Engineering Laboratory (INEL) is a U. S. Department of Energy (DOE) research facility that deals, in part, with studying nuclear reactors and storing radioactive materials. Careful handling and rigorous procedures do not completely eliminate the risk of releasing radioactivity. So, there is a remote possibility for a member of the public near the INEL to be exposed to radioactivity from the INEL.

Extensive monitoring of the environment takes place on and around the INEL. These programs search for radionuclides and other contaminants. The results of these programs are presented each year in a site environmental report. This document summarizes the Idaho National Engineering Laboratory Site Environmental Report for Calendar Year 1995.

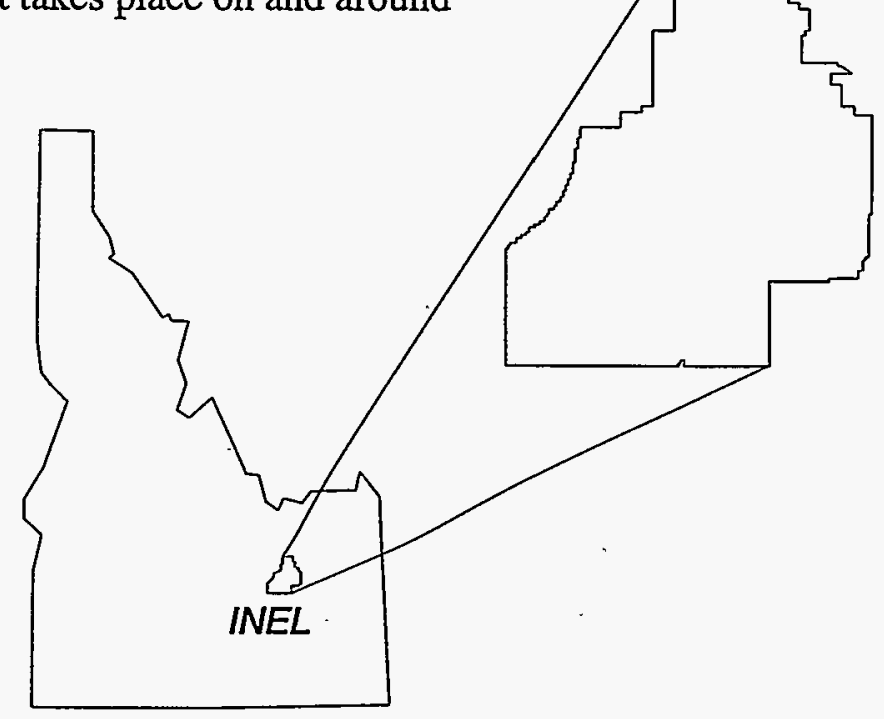

The INEL is located in southeast Idaho. 


\section{INEL History}

This federal reserve was founded by DOE's predecessor, the Atomic Energy Commission, as the National Reactor Testing Station in 1949. The Site was selected as a remote place for building and testing nuclear reactors. It was renamed the INEL in 1974 to better reflect its expanded mission. Today, the INEL's mission encompasses advanced systems engineering, safe storage of radioactive waste, hazardous waste and spent nuclear fuel, and environmental management. It employs more than 8,000 people and operates on a budget of about $\$ 750$ million. In the quest for a safe and economical new source of energy for the United States, 52 reactors have been built at the INEL. Of these 14 are still operable or operating.

\section{Where is the INEL?}

Located on the eastern Snake River Plain of southeastern Idaho at an average elevation of 4,900 feet, the INEL encompasses 890 square miles. It extends 39 miles from north to south and is up to 36 miles wide in its southern portions. The land is a high, cool desert, known as a sagebrush steppe. The INEL's activities take place largely at eight facilities. Most of the INEL's land is open, with about 94 percent of the Site undeveloped. Lands immediately beyond the boundaries of the INEL are either open desert or farms, with most of the nearby farming conducted northeast of the INEL. About 60 percent of the INEL's lands are open to grazing. 
Beneath the INEL is the Snake River Plain Aquifer, a vast underground water body.

Most of the water in the aquifer comes from the mountainous area around the Henry's Fork of the Snake River, with additional contributions from the Big and Little Lost Rivers, and the Birch Creek drainages. The underground water moves southwest at a rate of about 5 to 20 feet per day. It reappears in springs along the Snake River between Burley and Bliss, Idaho. Both the ground water and surface waters of the Snake River Plain are used for crop irrigation and drinking water.

\section{INEL Facilities}

During 1995, six of the eight major INEL facilities were operated by Lockheed Martin Idaho Technologies Company (LITCO), which received a consolidated contract for the Site in October 1994. The Naval Reactors Facility is managed by Westinghouse Electric Corporation and Argonne National Laboratory-West is managed by the University of Chicago. Several INEL buildings in Idaho Falls house research, support and oversight personnel.

The eight major facilities at the INEL are:

- $\quad$ Argonne National Laboratory-West (ANL-W)

- Idaho Chemical Processing Plant (ICPP)

- Test Area North (TAN)

- $\quad$ Test Reactor Area (TRA)

- $\quad$ Power Burst Facility (PBF)

- Naval Reactors Facility (NRF)

- Radioactive Waste Management Complex (RWMC)

- Central Facilities Area (CFA) 


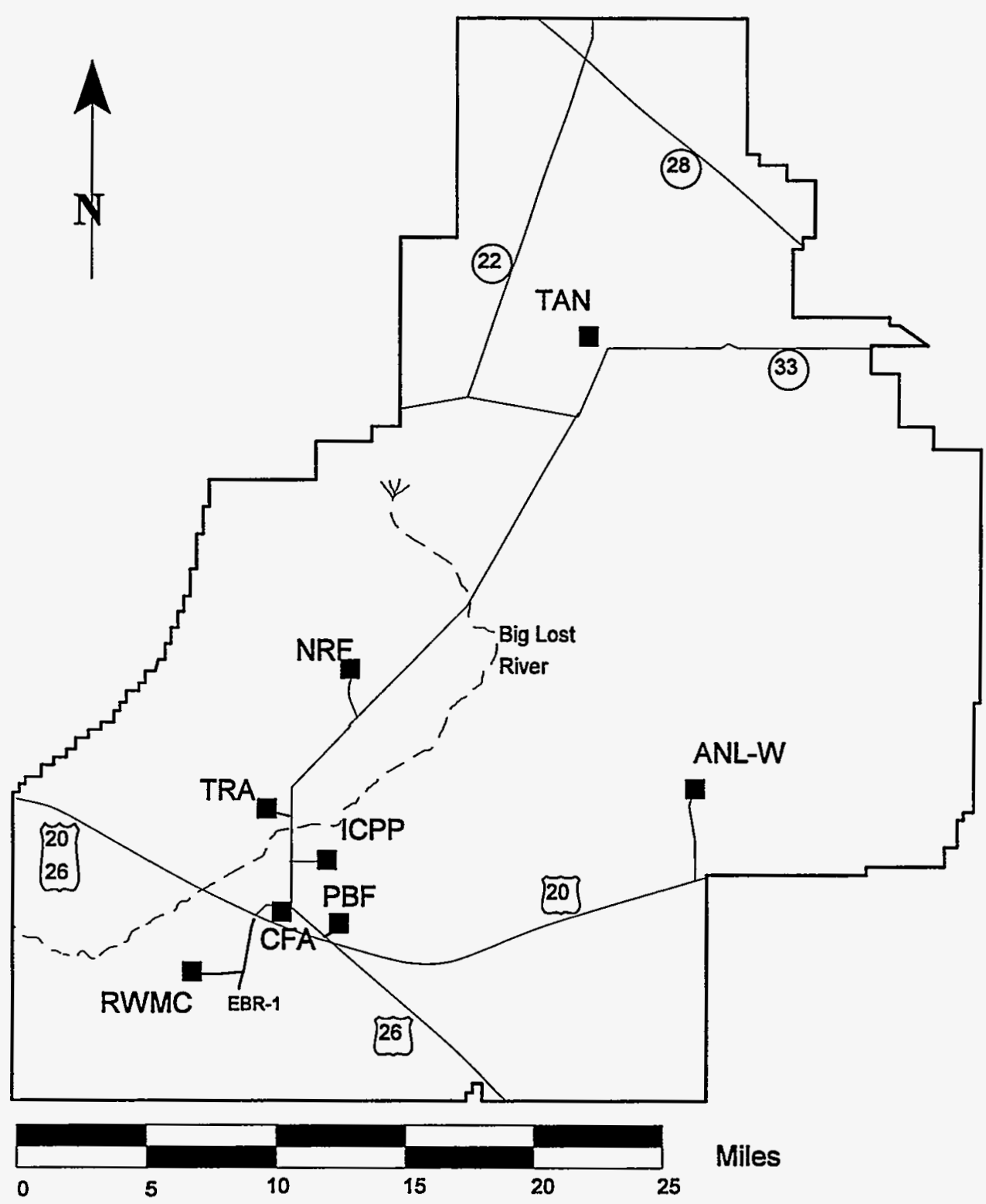

The INEL has eight major facilities within its 890 square-mile area. 


\section{Environmental Laws and Regulations}

The INEL strives to operate in compliance with all environmental laws, regulations, executive orders, DOE Orders, and compliance agreements with the Environmental Protection Agency and the State of Idaho. Major environmental laws and regulations include:

- $\quad$ Comprehensive Environmental Response, Compensation and Liability Act (Superfund)

- $\quad$ Emergency Planning and Community Right-to-Know Act

- Clean Air Act

- Clean Water Act

- $\quad$ State of Idaho Wastewater Land Application Permit Regulations

- Resource Conservation and Recovery Act

- National Environmental Policy Act

- $\quad$ Safe Drinking Water Act

- National Historic Preservation Act

- Native American Grave Protection and Repatriation Act

- $\quad$ Endangered Species Act

Chapter 2 in Idaho National Engineering Laboratory Site Environmental Report for Calendar

Year 1995 reviews the current compliance status with these environmental statutes.

Two of the largest programs at the INEL are Environmental Restoration and Waste Management. The Environmental Restoration Program focuses on cleanup activities. These include stabilizing contaminated soil; pumping, treating, and containing ground water; decontaminating, decommissioning, and demolishing abandoned buildings; and exhuming sludge and buried drums of waste. To facilitate this complex process, the INEL was divided into 10 Waste Area Groups (WAGs). Within each WAG are up to as many as 70 individual studies involving waste. Each WAG is undergoing, or will begin in 1996, a comprehensive investigation 
to determine what is known about the contamination there, if anything more needs to be learned, and what risks the contamination poses. Based on this information, a cleanup plan is proposed. After a period of public scrutiny, a revised plan for each WAG is implemented. Comprehensive investigations take an average of two years to complete.

The Waste Management Program aims to protect humans and the environment, while properly handling, treating, storing, and disposing of wastes at the INEL. An emerging philosophy is to prevent generating pollution in the first place, and to minimize the amount when waste production cannot be avoided. As a major component of this program, the INEL recently was named the lead DOE laboratory in devising new technology and techniques for managing mixed waste - that which is both hazardous and radioactive.

Chapter 3 in Idaho National Engineering Laboratory Site Environmental Report for Calendar Year 1995 explains the activities of the Environmental Restoration and Waste Management programs in more detail. 


\section{Environmental Monitoring}

Normal operations at INEL facilities regularly release various materials into the environment. These releases may contain radioactive materials, though they often do not. An extensive environmental monitoring program is conducted to identify and quantify all releases resulting from INEL activities.

\section{Why Monitor the Environment?}

According to agency regulations as well as federal and state laws, environmental surveillance must be conducted to monitor the environmental effects, if any, of DOE activities. The environmental monitoring and surveillance programs are designed to:

- protect the health of the public and environment;

- verify compliance with applicable environmental laws and tegulations, and with commitments made tn offictal DOE documents;

- look for trends in the physical, chemical and biological conditions of the environment on and around the. INEL;

- assess the potential radiation dose to members of the public from INEL operations.

\section{Monitoring vs. Surveillance: What's the Difference?}

Environmental monitoring consists of two separate activities: effluent monitoring and environmental surveillance. Effluent monitoring measures contaminants where they are released. Environmental surveillance looks for and measures contaminants that have dispersed into the environment. Potential environmental pathways by which contaminants could be transported 
from the INEL include foodstuffs grown in the vicinity of the INEL, inhaled air, game animals which live on the INEL and are later taken by hunters, and ground and surface water.

The operating contractors at each INEL facility are responsible for monitoring the releases from their facilities and for any surveillance performed within their facility fences. Results of these programs are reported annually by each organization. Throughout 1995 , the onsite environmental surveillance program for the INEL was conducted by LITCO. The offsite portion of the environmental surveillance program was conducted by the Environmental Science and Research Foundation, a nonprofit organization also active in INEL ecology research and

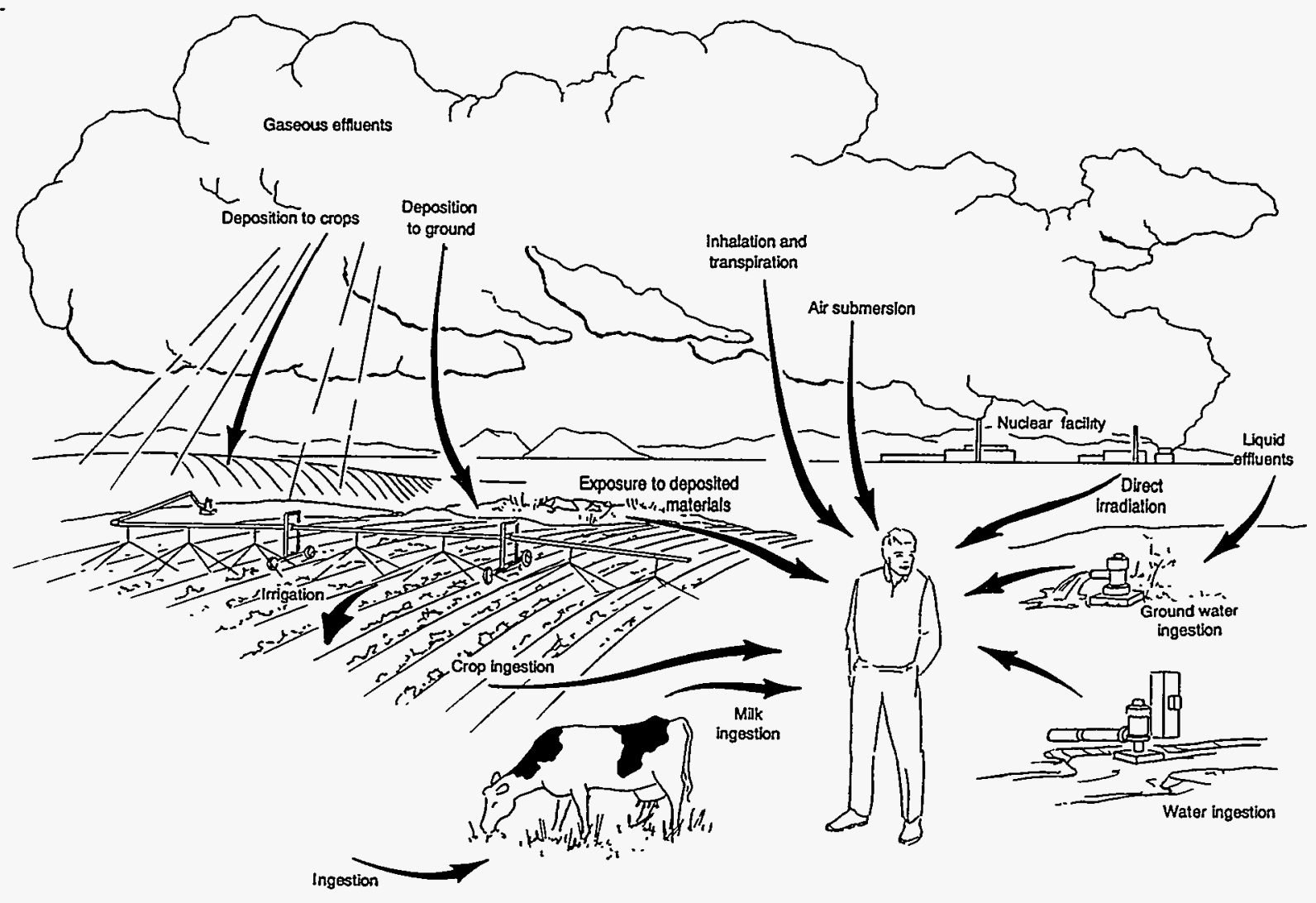

Potential environmental pathways from the INEL to humans. 
environmental education. Ground-water surveillance was conducted by the U.S. Geological Survey (USGS), and weather patterns were characterized by the National Oceanic and Atmospheric Administration (NOAA). These data were used in part to compute radiation doses to members of the public. An independent verification program was also operated by the State of Idaho INEL Oversight Program. 


\section{Program Descriptions}

\section{Speaking the Radiation Language}

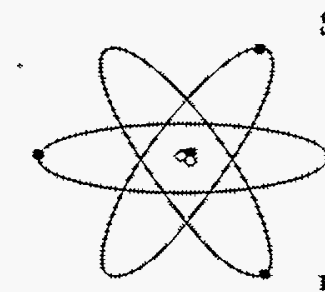

Samples from environmental pathways and effluent streams are tested for radioactivity and other confamination. When discussing resulfs from these tests, scientists use many special terms. In otder to understand the implications of the results of these tests, one must first understand the radiation "language."

Some atoms contain too much energy and are unstable. They try to become stable by releasing their excess energy as either waves or particles. These waves and particles are called radiation.

A radionuclide is a radioactive form of an element. For example, tritium is a zadioactive form of hydrogen.

A curie is a unit used to measure the amount of tadioactivity in a sample. It is abbreviated as $\mathbf{C r}$.

A rem is a unit used to measure the amount of radiafion dose to humans. A millirem is $1 / 1000$ (one thousandth) of a rem.

A person-rem is the sum of the radiation doses received by all individuals in a population. This concept can also be expressed in person-millirem.

Gross analyses detect the total amount of specific types of radioactivity (alpha, beta, gamma) in a sample, but do not identify the individual radionuclides.

Half-life is the time required for one-half of a radioactive material to decay. Therefore, the shorter the half-life, the faster a radioactive material decays.

\section{Radiological Surveillance Program}

Air is the most direct pathway for contaminants from the INEL to reach the offsite environment. Therefore, air is sampled more frequently than other pathways. Both high-volume and low-volume air samplers were used to measure airborne radioactivity. Air filters from the high-volume samplers were changed daily; whereas filters from the low-volume samplers were 
changed weekly. LITCO operated two high-volume air samplers on the INEL. A total of 15 low-volume air samples were located on the INEL, and an additional 15 low-volume air samplers were located off of the INEL.

Monthly precipitation samples were collected in Idaho Falls and on the INEL; a weekly sample was collected on the INEL when there was measurable precipitation. INEL contractors collected onsite drinking water samples from their facilities each month during January through June; a quarterly schedule was adopted beginning in July, except at NRF which continued sampling monthly. The Foundation collected water from the Snake River and from 14 drinking water supplies, at both boundary and distant locations, twice per year. In addition, the Foundation also collected quarterly samples from three springs in the Magic Valley of southcentral Idaho.

No streams or rivers flow from within the INEL to offsite locations. But, water monitoring is still an important surveillance activity because the INEL is located directly above the Snake River Plain Aquifer and past waste management practices included injecting wastes directly into the aquifer. The U.S. Geological Survey (USGS) monitors the Snake River Plain Aquifer under and near the INEL, as well as "perched" pockets of ground water above the aquifer. Perched water is not at the surface, nor is it part of the aquifer.

The USGS maintains about 125 aquifer observation wells, 40 wells for sampling perched water, and more than 120 auger holes to monitor shallow perched water. They test samples for both radiological and non-radiological contaminants. The USGS also publishes special studies detailing conditions in the aquifer. Documents released in 1995 included reports on aquifer-wide 
water movement and pollution; contaminants in selected wells between the INEL and Hagerman, Idaho; chemicals found in wells near NRF; and the geology and chemical composition of rocks beneath the INEL. For more information about the USGS water monitoring program, call the USGS INEL Project Office, (208) 526-2438.

The Foundation collected samples of milk, wheat, garden lettuce, and potatoes, from places near the INEL boundary as well as distant from the INEL. They also sampled liver, thyroid, and muscle tissues from sheep that grazed on the INEL and of big game animals accidentally killed on INEL roadways. Sheep and game animals represent a potential pathway to people who might consume animals that came into contact with contaminants while on the INEL. Milk, wheat, lettuce, and potatoes were included in the program because they are a part of a typical American diet and represent potential pathways for radionuclides from INEL operations. Potatoes are also an important agricultural crop and source of revenue for southeast Idaho.

\section{Game Ingestion Pathway}

The NEL is home to hundreds and hundreds of game animals, many of which leave the INEL durng summer and autumn, and can be hunted during regular hunting seasons. The potential dose to an individual from ingestion of meat from game animals is calculated.

Results of a 1984-86 study of waterfowl using radioative waste ponds on the INEL tound that the potential dose to a person eating the entire liver and muscle mass of the most contaminated duck in the study was 4.0 millirem. The group of ponds where this duck was taken have since been drained and replaced by ponds with plastic liners. A new study is underway to determine the effect of the lined ponds on radionuclide concentrations in waterfowl.

Pronghorn antelope are the INEL's most visible game animal. An estimate of the dose to a petson eating the entire muscle and liver mass of an INEL pronghorn with the highest level of radionuclides found during the last five years is 0.03 millirem. (A more complete discussion of dose begins on page 24 .) 
Soil is sampled by the Foundation during even-numbered years. So, it was not part of the routine surveillance program for 1995 . Onsite, soil at facilities is collected on a seven-year rotating schedule.

Environmental dosimeters were used to directly measure radiation in the environment. They were placed at seven distant locations, six boundary locations, and 135 locations on the INEL. Dosimeters were collected for analysis in May and November. 


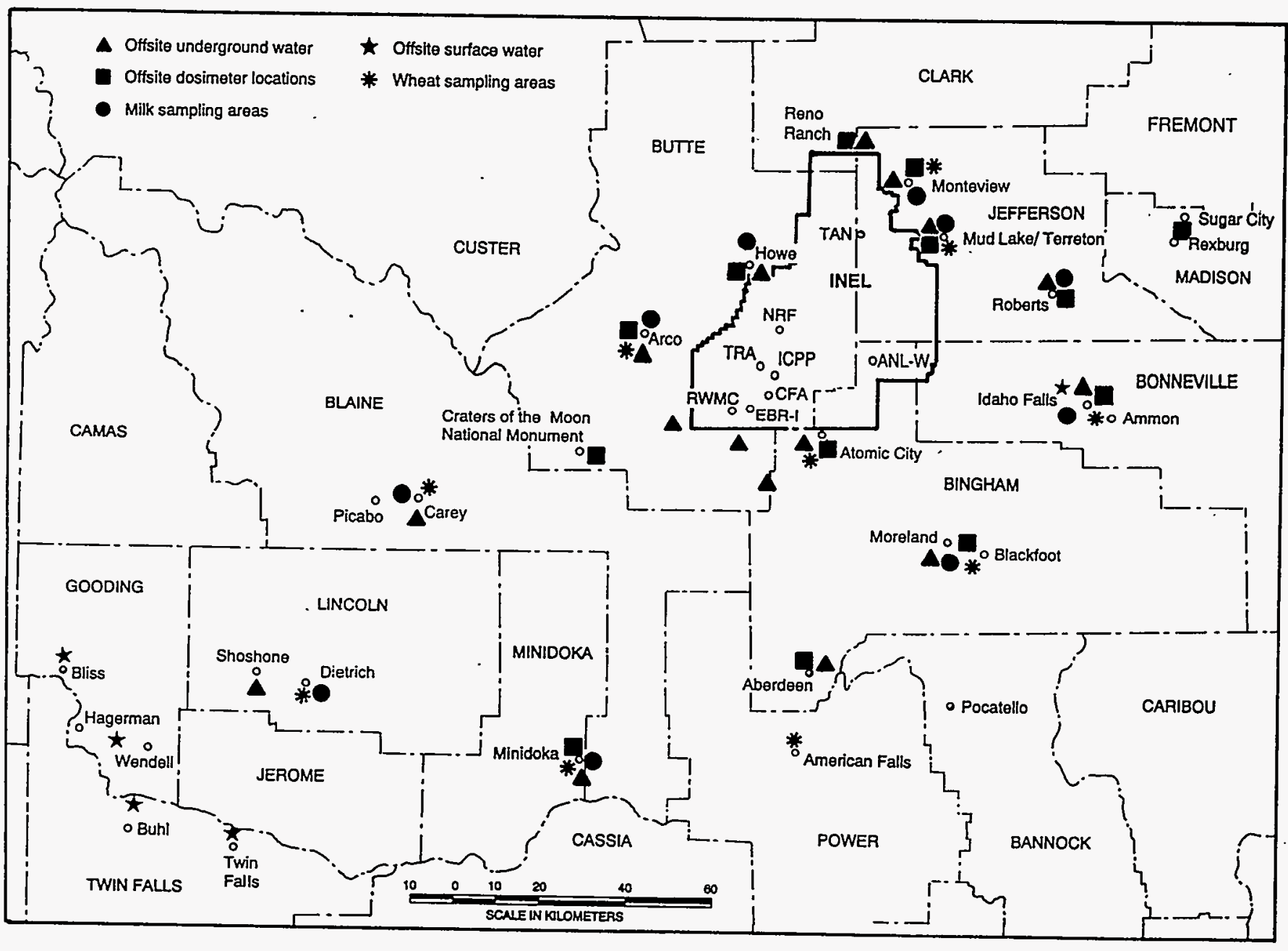

Water, food, and environmental dosimeter sampling locations around the INEL. 


\section{Radiological Effluent Monitoring Program}

Known and measured amounts of radionuclides were released as airborne and liquid effluents at the INEL in 1995. Airborne and liquid effluents released to the environment were carefully monitored at potential release points. INEL contractors report these releases using several methods, as required by $\mathrm{DOE}$ as well as state and federal regulations. 


\section{Nonradiological Monitoring Programs}

In addition to monitoring for radioactive contaminants in the environment, the INEL's surveillance program also routinely checks for nonradiological contaminants in the air and water. Air is monitored for particulates. These tiny particles, such as dust, nitrogen oxides, and sulfur

\section{What Are $\mathrm{NO}_{\mathrm{x}}$ and $\mathrm{SO}_{\mathrm{x}}$ ?}

Under the federal Clean Air Act, two pollutants of concern are oxides of nitrogen $\left(\mathrm{NO}_{\mathrm{x}}\right)$ and sulfur $\left(\mathrm{SO}_{x}\right)$. Each of these elements have more than one oxide. For instance, two common nitrogen oxides are nitrogen oxide (NO) and nitrogen dioxide $\left(\mathrm{NO}_{2}\right)$ and two common sulfur oxides are sulfur dioxide $\left(\mathrm{SO}_{2}\right)$ and sulfur trioxide $\left(\mathrm{SO}_{3}\right)$. Three of these four pollutants are measured at the INEL: nitrogen oxide, nitrogen dioxide, and sulfur dioxide.

At the INEL, these pollutants are measured at their .source (as they are emitted from stacks) and in the environment. The amount that can be emitted is limited by permits issued by the State of Idaho. Concentrations found in the enyironment must be within standards set by the federal Environmental Protection Agency.

of waste at ICPP, the burning of coal, the

burning of heating oil, motor vehicle exhausts, and dust produced by construction activities.

Liquid effluents, including sewage, chemicals used for water treatment, and cleansers, are monitored and reported in many of the same oxides, can impair visibility and may cause breathing problems. Particulate concentrations were measured with the same low-volume air samplers used for radiological measurements.

The five major sources of these

nonradiological airborne emissions at the INEL are nitrogen dioxide emissions from treatment

\section{What is IMPROVE?}

Interagency Monitoring of Protected Visual Environments (MPROVE) is a program designed to test for visiblify at national parks, monuments and wilderness areas throughout the United States.

In 1992, an IMPROVE sampler was set up on the INEL, and another was established at Craters of the Moon National Monument, through a Memorandum of Understanding between the National Bark Service and DOE.

MPROVE sample analyses are performed by the Crocker Nuclear Laboratory at the Uniyersity of California, Davis.

ways. 


\section{Radiological Results}

\section{Radiological Surveillance Results}

Radiological environmental surveillance for 1995 found that most radioactivity from INEL operations could not be distinguished from worldwide weapons testing fallout and natural radioactivity. Offsite data indicated no measurable human health risks due to INEL operations. By comparison, each person in southeastern Idaho receives an annual radiation dose of about 360 millirem from sources besides the INEL. This is referred to as background radiation.

\section{Radiological Effluent Monitoring Results}

A total of 1,380 curies of airborne radionuclides were released during INEL operations in 1995. More than 99 percent of this radioactivity was in the form of short-lived and non-reactive gases. Because of rapid decay, the actual radioactivity that reached offsite areas was considerably less than 1,380 curies.

Radioactive liquids were placed into specially designed evaporation and seepage ponds. No liquids were released directly to the offsite environment. All discharges directly into the Snake River Plain Aquifer ceased in 1984. More than 99 percent of this radioactivity was placed in a heavy plastic-lined pond at TRA. Of the 84 curies put into the pond in 1995,80 curies were from tritium, a radioactive form of hydrogen. 


\section{Radiological Surveillance Results for 1995}

\begin{tabular}{|c|c|c|}
\hline Medium & What Was Found & What It Means \\
\hline $\begin{array}{c}\text { Air } \\
\text { High Volume } \\
454 \text { high-volume air } \\
\text { filters were collected } \\
\text { and analyzed. }\end{array}$ & $\begin{array}{l}\text { No man-made radionuclides were } \\
\text { indicated on any daily filter. } \\
\text { - Several man-made radionuclides were } \\
\text { detected on monthly composites. }\end{array}$ & $\begin{array}{l}\text { All positive results were just above the } \\
\text { minimum detectable concentration, } \\
\text { and represents less than } 0.01 \text { percent } \\
\text { of DOE's concentration guides. }\end{array}$ \\
\hline $\begin{array}{l}\text { Low Volume } \\
\text { 1,560 low-volume air } \\
\text { filters were collected } \\
\text { and analyzed. }\end{array}$ & $\begin{array}{l}\text { During the year, a total of } 12 \text { man- } \\
\text { made radionuclides were defected } \\
\text { onsite, at a total on nine locations. } \\
\text { Plutonium and americium were } \\
\text { detected at the Radioactive Waste } \\
\text { Management Complex in the second, } \\
\text { third, and fourth quarters. Plutonitum } \\
\text { was detected at the Power Burst } \\
\text { Facility and Experimental Breeder } \\
\text { Reactor-1 in the second quarter. } \\
\text { Plutonium, americium, and strontium } \\
\text { were detected at the Idaho Chemical } \\
\text { Processing Plant in the third and } \\
\text { fourth quarters. } \\
\text { Americium was detected at several } \\
\text { offsite locations during the third and } \\
\text { fourth quarters. } \\
\text { - } \\
\text { Radioactive iodine was detected on } \\
\text { seven occasions. } \\
\text { radiation was measured on } 5 \text { percent. } \\
\text { of offsite filters and } 9 \text { percent of onsite } \\
\text { filters. }\end{array}$ & $\begin{array}{l}\text { The presence of the man-made } \\
\text { radionuclides plutonitum and } \\
\text { americium at the Radioactive Waste } \\
\text { Management Complex and } \\
\text { Experimental Breeder Reactor-I was } \\
\text { attributed to contaminated soil } \\
\text { particles made airborne by } \\
\text { construction activities. The } \\
\text { plutonium, americium, and strontium } \\
\text { detected at the Power Burst Facility } \\
\text { and Idaho Chemical Processing Plant } \\
\text { are of unknown origin. The highest } \\
\text { concentration indicated represents } 1,6 \\
\text { percent of DOE's concentration } \\
\text { gutdes. } \\
\text { The origin of the americiun was not } \\
\text { determined. This radionuclide is } \\
\text { present in soils worldwide as, a result } \\
\text { of muclear weapons testing during the } \\
\text { 1950s and } 1960 \text { s. } \\
\text { The concentration of iodine, likely } \\
\text { from INEL activities, was just above } \\
\text { the minimum detectable concentration, } \\
\text { and represents less than } 0.005 \text { percent } \\
\text { of DoE's concentration gutdes. } \\
\text { - Some of the differences detected may } \\
\text { be due to INEL operations, but no } \\
\text { specific sources could be identified. }\end{array}$ \\
\hline
\end{tabular}




\begin{tabular}{|c|c|c|}
\hline Medium & What Was Found & What It Means \\
\hline $\begin{array}{c}\text { Atmospheric } \\
\text { Moisture/ } \\
\text { Precipitation } \\
\\
19 \text { atmospheric } \\
\text { moisture samples were } \\
\text { collected and analyzed. } \\
\\
43 \text { precipitation } \\
\text { samples were collected } \\
\text { and analyzed. }\end{array}$ & $\begin{array}{l}\text { A greater number of positive } \\
\text { concentrations were measured, since } \\
\text { lower concentrations of tritium could } \\
\text { be detected. } \\
\text { - Tritium was detected in four offsite } \\
\text { atmospheric moisture samples. }\end{array}$ & $\begin{array}{l}\text { Improvements in laboratory techniques } \\
\text { resulted in a lower detection limits for } \\
\text { tritium. } \\
\text { - The highest concentration of tritium } \\
\text { was detected at a distant location. It } \\
\text { represents } 0.0007 \text { percent of DOE's } \\
\text { concentration guides. } \\
\text { - Higher concentrations of tritium were } \\
\text { detected at locations distant from the } \\
\text { INEL, indicating that natural } \\
\text { atmospheric processes and historic } \\
\text { weapons testing were the likely source } \\
\text { of the tritium. }\end{array}$ \\
\hline $\begin{array}{c}\text { Water } \\
51 \text { offsite water } \\
\text { samples were collected } \\
\text { and analyzed ( } 32 \\
\text { drinking water and } 19 \\
\text { surface water). } \\
224 \text { onsite water } \\
\text { samples were collected } \\
\text { from wells and } \\
\text { analyzed. }\end{array}$ & $\begin{array}{l}\text { Eight of the offsite water samples } \\
\text { contained detectable amounts of } \\
\text { tritium. } \\
\text { 15 onsite well samples had detectable } \\
\text { gross alpha radiation; } 39 \text { had } \\
\text { detectable concentrations of gross } \\
\text { beta. }\end{array}$ & $\begin{array}{l}\text { All gross alpha and beta } \\
\text { concentrations, except one, were } \\
\text { within the expected concentration } \\
\text { range for naturally occurring activity } \\
\text { in the Snake River Plain Aquifer } \\
\text { underlying the INEL and surrounding } \\
\text { areas. A sample from the Snake River } \\
\text { was found to contain excess sediment } \\
\text { which caused an unusually high gross } \\
\text { beta reading. } \\
\text { The highest offsite tritium } \\
\text { concentration represented } 0.02 \text { percent } \\
\text { of DOE's concentration guides. } \\
\text { All gross alpha readings and } 36 \text { of the } \\
\text { gross beta readings were within the } \\
\text { range expected for naturally occurring } \\
\text { activity in Snake River Plain Aquifer. } \\
\text { Three samples from the Idaho } \\
\text { Chemical Processing Plant had } \\
\text { elevated concentrations, possibly } \\
\text { related to a strontium plume beneath } \\
\text { the facility. }\end{array}$ \\
\hline
\end{tabular}




\section{Radiological Surveillance Results for 1995, continued}

\begin{tabular}{|c|c|c|}
\hline Medium & What Was Found & What It Means \\
\hline Water, continued & $\begin{array}{l}\text { Tritum was detected in samples from } \\
\text { Central Facilities Area, Idaho } \\
\text { Chemical Ptocessing Plant, INEL } \\
\text { Rifle Range, and Radioactive Waste } \\
\text { Management Complex. } \\
\text { Three onsite wells at Idaho Chemical } \\
\text { Processing Plant showed deteetable } \\
\text { concentrations of strontium. A } \\
\text { marked increase in strontium } \\
\text { eontentrations sas indicated in June. } \\
\text { An effective annual dose of } 0.7 \\
\text { millirem from drinking water was } \\
\text { estimated for workers at Central } \\
\text { Facilities Area, the INEL facility with } \\
\text { the highest concentration of tritium in } \\
\text { its water. }\end{array}$ & $\begin{array}{l}\text { - The water samples in which tritium } \\
\text { was detected at Central Facilities Area, } \\
\text { Idaho Chemical Processing Plant, } \\
\text { INEL Rifle Range, and Radioactive } \\
\text { Waste Management Complex were } \\
\text { collected from a contaminant plume } \\
\text { beneath the facilities. Its prescence } \\
\text { was previously known and the } \\
\text { concentrations show a downward trend } \\
\text { during the last five years. The plume } \\
\text { was not detected in offsite } \\
\text { groundwater. } \\
\text { - Ayerage concentrations of strontium at } \\
\text { Idaho Chemical Processing Plant were } \\
\text { consistent with findings from previous } \\
\text { years, thaugh it is unknown what } \\
\text { caused the peak in June. } \\
\text { The effective dose estimate of } 0.7 \\
\text { millirem for a worker at Central } \\
\text { Facilities Area represents } 18 \text { percent } \\
\text { of the federal community drinking } \\
\text { water standard, as set by the } \\
\text { Environmental Protection Agency. }\end{array}$ \\
\hline $\begin{array}{l}\text { Environmental } \\
\text { Dosimeters } \\
\\
287 \text { environmental } \\
\text { dosimeters were } \\
\text { collected and analyzed. }\end{array}$ & $\begin{array}{l}\text { No statistical differences were seen } \\
\text { between environmental radiation } \\
\text { measured at boundary and distant } \\
\text { locations. } \\
\text { - Onsite measures of environmental } \\
\text { radiation at Argonne National } \\
\text { Laboratory-West, Auxilliary Reactor } \\
\text { Area, Idaho Chemical Processing } \\
\text { Plant, Radioactive Waste Management } \\
\text { Complex, and Test Reactor Area were } \\
\text { higher than background. }\end{array}$ & $\begin{array}{l}\text { - Radiation exposures off the INEL } \\
\text { were not measurably increased due to } \\
\text { INEL activities. } \\
\text { - Higher radiation exposures at some } \\
\text { INEL facilities were found in the } \\
\text { vicinity of radioactive material storage } \\
\text { areas and areas with contaminated } \\
\text { soils. }\end{array}$ \\
\hline
\end{tabular}




\begin{tabular}{|c|c|c|}
\hline 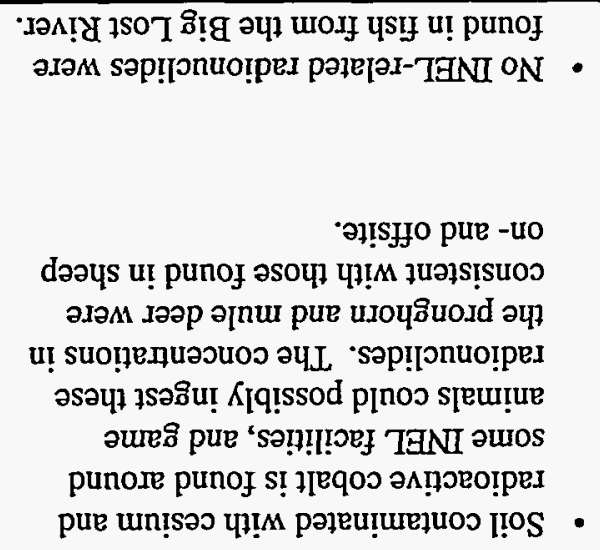 & 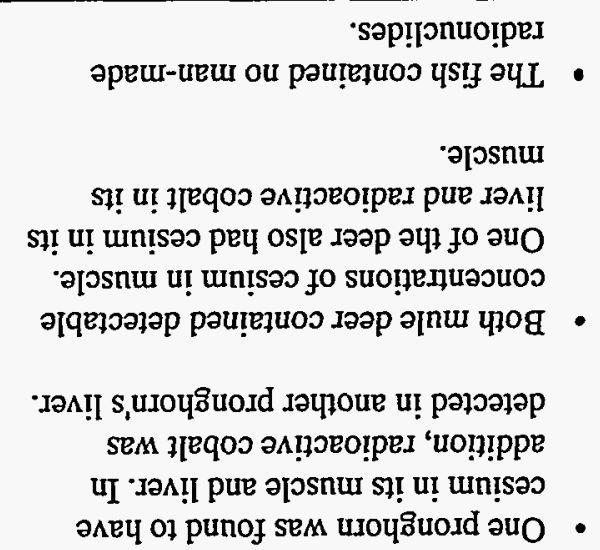 & 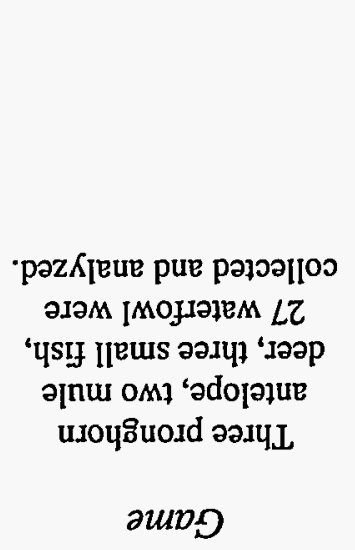 \\
\hline 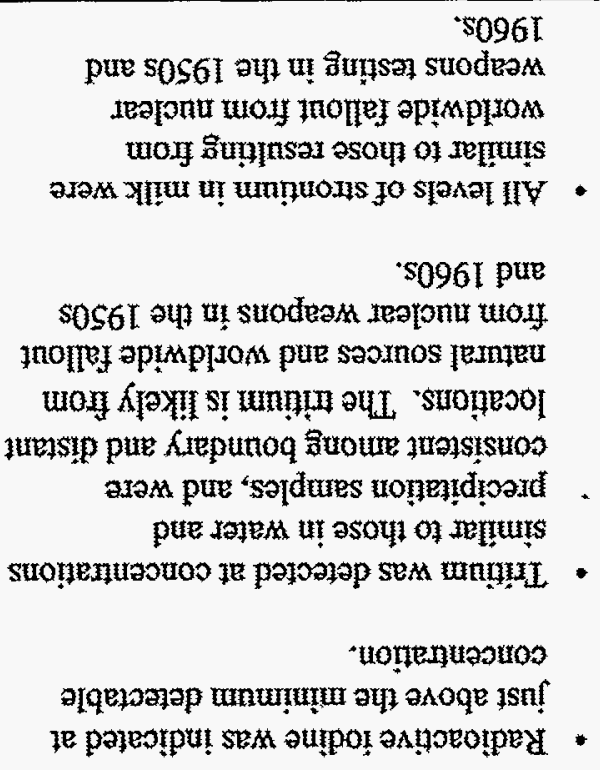 & 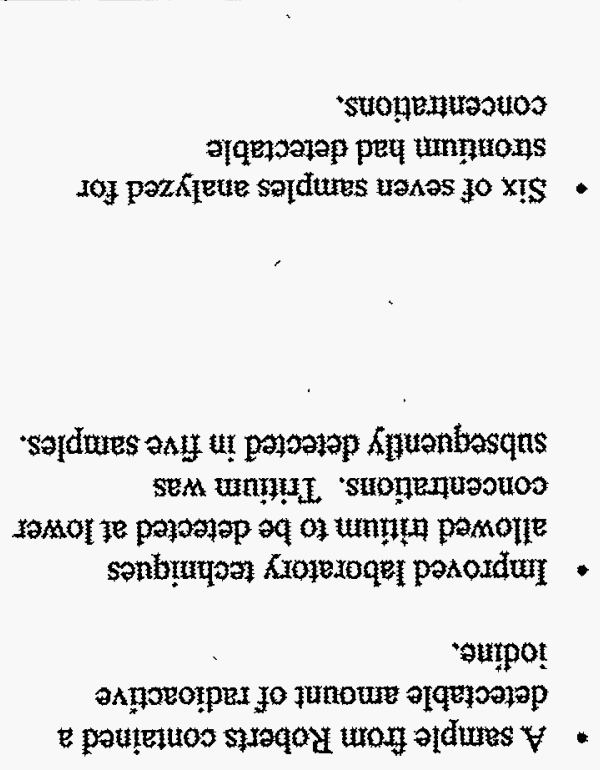 & 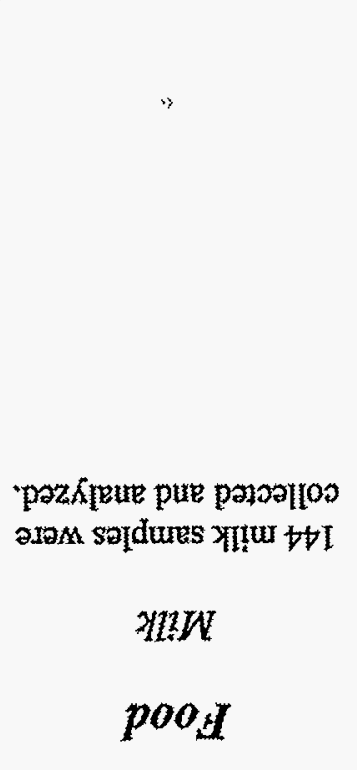 \\
\hline 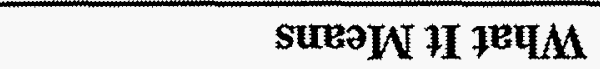 & 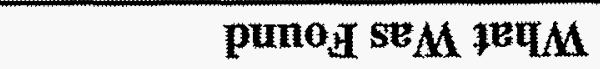 & urmIPaJA \\
\hline
\end{tabular}

\$661: :Lewumn UI 


\begin{tabular}{|c|c|c|}
\hline Medium & What Was Found & What It Means \\
\hline Game, continued & $\begin{array}{l}\text { - Man-made radionuclides were } \\
\text { detected in waterfowl from all five } \\
\text { locations sampled, including a wetland } \\
\text { distant from the INEL. Three birds } \\
\text { taken at Test Area North contained } \\
\text { above-background concentrations of } \\
\text { cesium. }\end{array}$ & $\begin{array}{l}\text { - Most concentrations represented } \\
\text { background radiation, the source of } \\
\text { which is natural processes and } \\
\text { worldwide fallout. The waterfowl } \\
\text { from Test Area North were collected } \\
\text { from a pond known to have cesium in } \\
\text { the underlying soil. A dose of } 0.018 \\
\text { millirem was estimated if a person } \\
\text { were to eat the entire edible portion of } \\
\text { the most contaminated bird. That's } \\
\text { 0.00005 percent of the average annual } \\
\text { dose of } 360 \text { millirem for each person } \\
\text { in southeastern Idaho. }\end{array}$ \\
\hline $\begin{array}{l}\text { Lettuce } \\
\text { Seven samples were } \\
\text { collected and analyzed. }\end{array}$ & $\begin{array}{l}\text { Cesium was detected in fwo lettuce } \\
\text { samples and strontium was detected in } \\
\text { all samples. }\end{array}$ & $\begin{array}{l}\text { The maximum concentration of both } \\
\text { cesium and strontium were found at } \\
\text { the distant location of Blackfoot. The } \\
\text { likely source of these man-made } \\
\text { radionuclides is worldwite fallout } \\
\text { from nuclear weapons testing in the } \\
1950 \text { s and } 1960 \mathrm{~s} \text {. }\end{array}$ \\
\hline $\begin{array}{l}\text { Wheat } \\
10 \text { wheat samples were } \\
\text { collected and analyzed. }\end{array}$ & $\begin{array}{l}\text { - Strontium was detected in seven wheat } \\
\text { samples. }\end{array}$ & $\begin{array}{l}\text { The concentrations are within the } \\
\text { range known to result from fallout } \\
\text { from above-ground nuclear weapons } \\
\text { testing of the } 1950 \text { s and } 1960 \text { s. }\end{array}$ \\
\hline $\begin{array}{l}\text { Potatoes } \\
\text { Five potato samples } \\
\text { were collected and } \\
\text { analyzed. }\end{array}$ & $\begin{array}{l}\text { Strontium was found in four of the } \\
\text { potato samples. }\end{array}$ & $\begin{array}{l}\text { The concentrations are within the } \\
\text { range known to result from fallout } \\
\text { from above-ground nuclear weapons } \\
\text { festing of the } 1950 \text { s and } 1960 \text { s. }\end{array}$ \\
\hline $\begin{array}{c}\text { Sheep } \\
\text { Six sheep were } \\
\text { collected and analyzed } \\
\text { (four that had grazed } \\
\text { onsite and two that had } \\
\text { grazed offsite). }\end{array}$ & $\begin{array}{l}\text { - Cesium was detected in the muscle of } \\
\text { three of four onsite sheep and one of } \\
\text { two offsite sheep. }\end{array}$ & $\begin{array}{l}\text { All cesium concentrations were similar } \\
\text { to those found previously in both } \\
\text { onsite and offsite sheep samples } \\
\text { previously. The radionuclide is likely } \\
\text { due to worldwide fallout. }\end{array}$ \\
\hline
\end{tabular}




\section{Nonradiological Results}

Surveillance data indicated that particulate concentrations were greater at distant and boundary locations than on the INEL. Nitrogen dioxide and sulfur dioxide levels recorded on the INEL averaged less than five percent of Environmental Protection Agency standards. The primary source for particulates in the air on and around the INEL was considered to be soil blowing off farm fields. Data from IMPROVE samplers operated on the INEL and at Craters of the Moon National Monument were examined. Analyses on these samples provided information about the presence of 26 different elements in air samples. No substantial differences were noted for results between the two locations.

Concentrations of contaminants in liquid waste streams were found to comply with environmental laws and regulations. The largest INEL liquid waste stream, service waste from ICPP, was monitored monthly through sampling and analysis.

Testing of drinking water at facilities found coliform bacteria in samples 10 times during the year. Additional chlorination purified the water in each case. Regulatory standards were exceeded twice; the $\mathrm{pH}$ at TRA was $8.8 \mathrm{in}$ June (standard is 8.5 ) and surfactants of 0.6 milligrams per liter were found at ICPP in October (standard is 0.5 milligrams per liter).

Cleansing of organic chemicals from wells at TAN continued. These actions began in 1988. Some workers at TAN drink bottled water because of these contaminants.

USGS analyses found organic chemicals in previously known waste plumes beneath ICPP, NRF, RWMC, and TRA. Concentrations were similar to those previously reported. 


\section{Radiation Dose Estimates}

Radiation from INEL operations was not detected by offsite environmental surveillance methods in 1995. This is usually the case. Because doses to the public are generally too small to be measured, computer models are used to estimate annual radiation doses from the INEL. Two models were used, and the higher dose estimate from INEL activities was 0.018 millirem. That's only 0.005 percent of an average person's annual dose from background sources. And, this is a dose for the "maximally exposed individual"—someone who spent the entire year living at a certain point near the INEL boundary, which for 1995 was at Frenchman's Cabin at the foot of Big Southern Butte.

The two models used each provide slightly different information. The first model used (CAP-88) is required by the Environmental Protection Agency for use at all DOE sites; whereas the second model (MESODIF) was created specifically for the INEL. The CAP-88 model resulted in a hypothetical maximum dose of 0.018 millirem. The MESODIF model produced an estimated dose of 0.008 millirem, occurring near Mud Lake. The dose estimates from these computer models can be compared to the average annual dose of 360 millirem in southeast Idaho.

A collective dose to the entire human population living within 50 miles of the center of the INEL is also calculated as part of MESODIF. This calculation considers all the pathways, the number of people in each locale, and the ways contaminants disperse from the INEL. The total potential population dose for the 121,500 people within 50 miles of the INEL's center was 
0.08 person-rem, or 80 person-millirems. The largest person-rem for specific locales are in the Idaho Falls and Hamer census divisions. Idaho Falls has a relatively large population, whereas the Hamer division, which includes the communities of Hamer, Monteview, Mud Lake, and Terreton, lies in the path of prevailing daytime winds. By comparison, background radiation exposure accounts for $42,525,000$ person-millirems to the same population in southeastern Idaho.

\section{Radiation Doses From Some Natural and Man-made Sources}

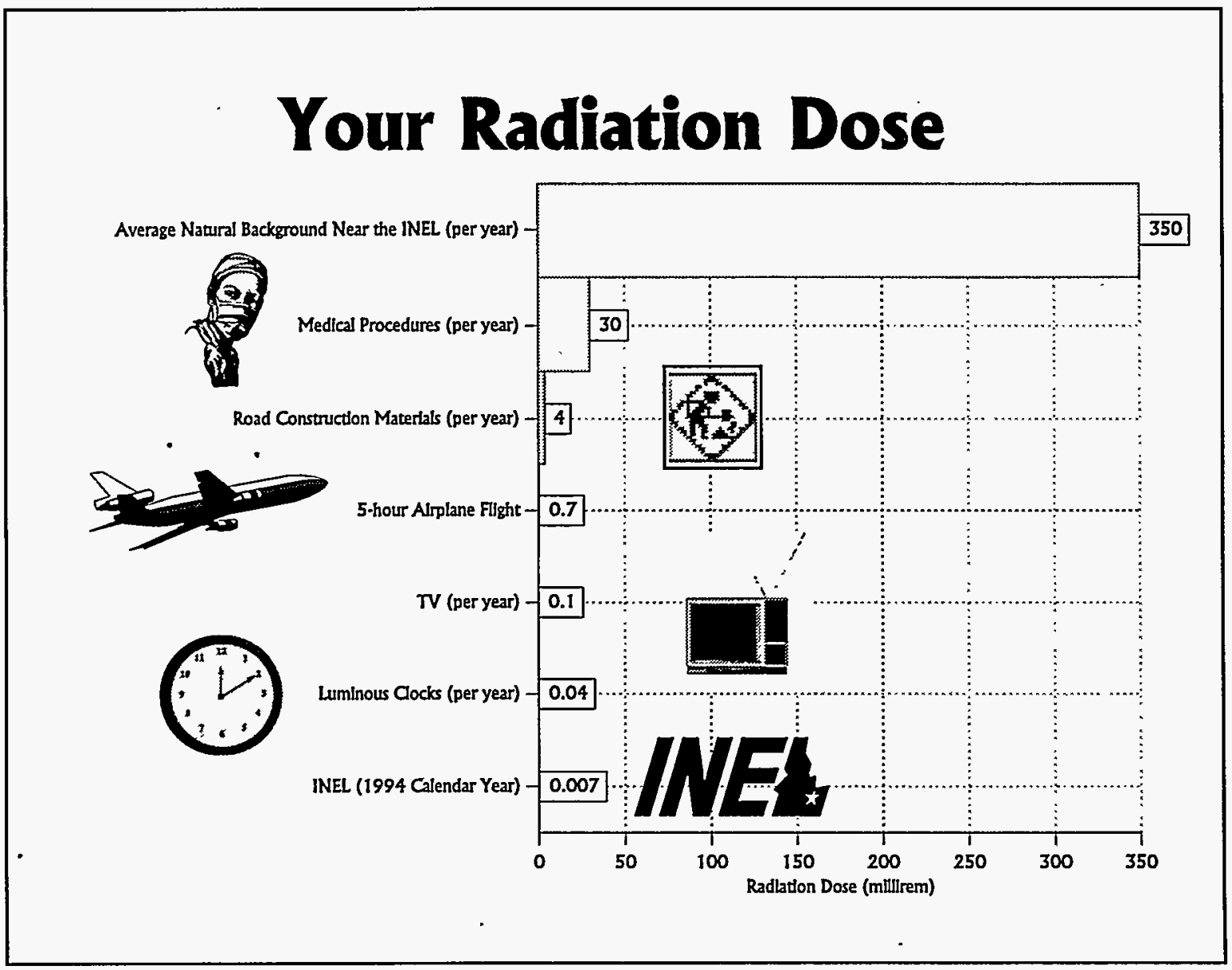




\section{Quality Assurance}

In order to be sure that the INEL's environmental monitoring programs are getting accurate and reliable results, each organization maintains quality control and assurance programs.

Laboratories performing analyses for these programs also have quality assurance programs. The laboratories also participate in national performance evaluation programs that further show the high quality of their data.

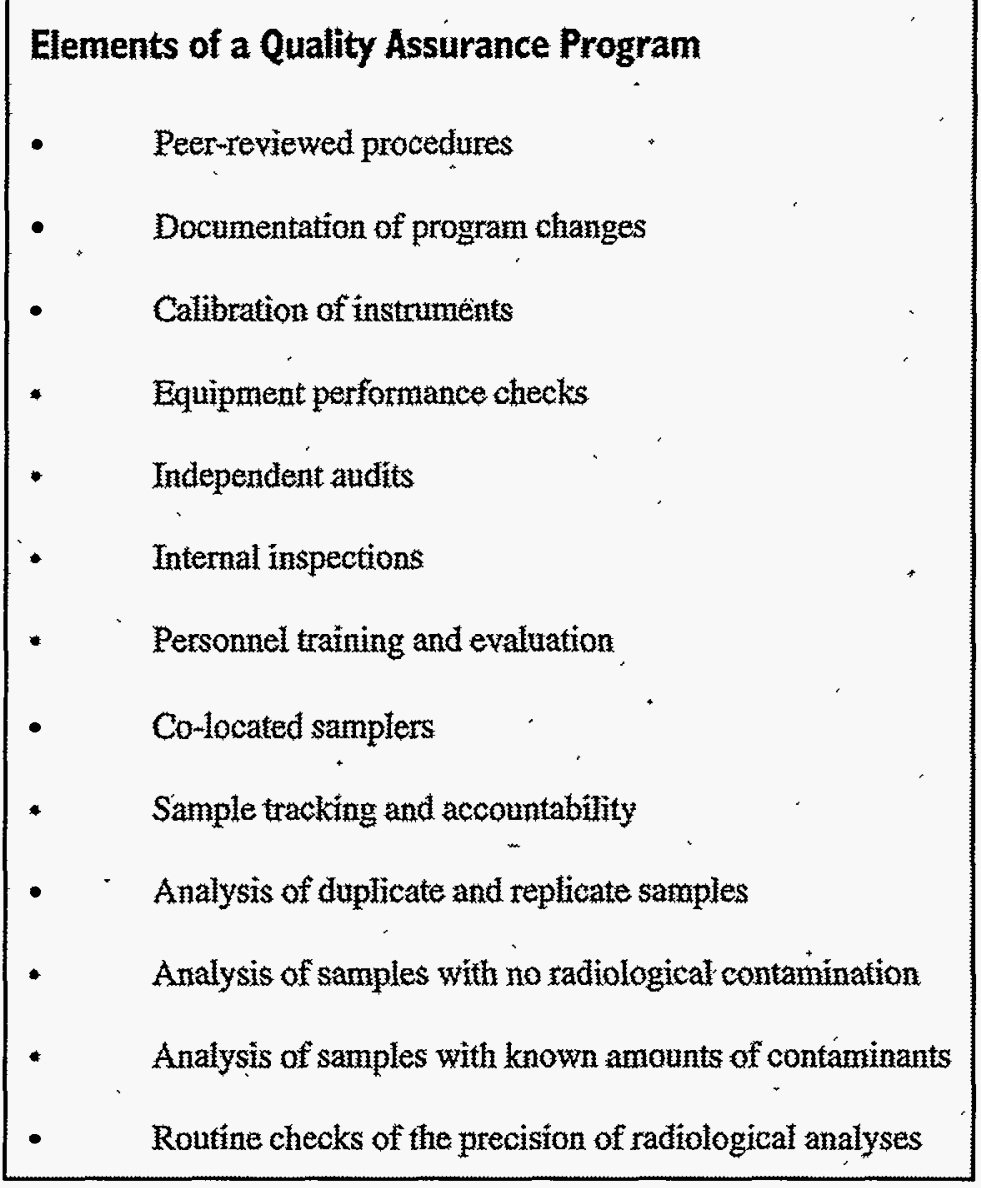


. 